\title{
Characterization Petrophysical of the Losero Formation in the Historical Architecture of the Guanajuato city, Mexico
}

\section{Caracterización petrofísica de la Formación Losero en la arquitectura histórica de la ciudad de Guanajuato, México}

\author{
Puy-Alquiza María Jesús \\ Departamento de Minas, Metalurgia y Geología \\ Universidad de Guanajuato, México \\ E-mail:yosune@ugto.mx \\ Miranda-Avilés Raúl \\ Departamento de Minas, Metalurgia y Geología \\ Universidad de Guanajuato, México \\ E-mail: rmiranda@ugto.mx \\ Salazar-Hernández Carmen \\ Unidad Interdisciplinaria de Ingenierías Campus Guanajuato \\ Instituto Politécnico Nacional (IPN) \\ E-mail:msalazarh@ipn.mx.com
}

\author{
Vega-González Marina \\ Universidad Nacional Autónoma de México (UNAM) \\ Campus Juriquilla Querétaro, México \\ E-mail:mvega@geociencias.unam.mx.com
}

Cervantes-Jauregui Jorge Armando

Departamento de Química

Universidad de Guanajuato, México

E-mail:jauregi@quijote.ugto.mx.com

Information on the article: received: October 2011, accepted: August 2012

\begin{abstract}
The Losero Formation has made an important contribution to the cultural and architectural heritage of Guanajuato city. The green color attractive appearance of this stone and its ease to be worked adds a number of significant landmarks of Guanajuato city. It was the most important natural building stone in the Guanajuato in the XVIII and XIX centuries. The Losero Formation is generally used as load-bearing material and, due to its lower porosity, as basal facings of the examined buildings. It also represents the main architectural elements in Guanajuato city, which is considered a world heritage site. After almost a century of exposure, the Losero Formation presents a progressive decay in many buildings (corrosion, scaling, spalling lichens, and crack formation). In some cases partial and total replacements have been successful in the restoration work, a proper understanding of the cause of decay is necessary for conservation purposes and restoration methodologies. This paper reports the findings of a petrophysical study of the eight lithofacies most used of the Losero Formation
\end{abstract}

\section{Keywords:}

- Losero Formation

- Guanajuato city

- petrography

- petrophysic

- construction and restoration 
in the restoration and construction of monuments in the city of Guanajuato (Los Morados, La Veta, Coleto, El Blanquito, El Moyejón, El Verde, La Perla, and La Cema), the names assigned to the lithofacies are informal and were called so by local stonemasons. This lithofacies were investigated by the techniques of optical microscopy; X-ray diffraction and Scanning Electron Microscopy (SEM) and physical properties (uniaxial compressive strength, capillarity water absorption, apparent and real density, total porosity) and durability using the salt crystallization test. The analytical results support that La Veta is the best lithofacie of Losero Formation which made it an ideal material for columns, pedestals, staircases, flooring, while that of La Cema cannot be used as pillars, balconies, and floors. The presence of calcite and kaolinite in La Veta and La Cema was not favorable for outdoor use. La Perla, El Moyejón and Coleto, were found to be an ideal material for columns, pedestals, staircases, flooring. Los Morados, El Blanquito, and El Verde exhibited low strength and durability values so cannot be used as pillars, balconies, and floors. These materials, notwithstanding their different behavior towards decay agents, are all affected by similar weathering typologies that, in order of importance and extension are: back weathering, break out, discoloration, soiling, lichen and fissures. The rate of decay depends on the textural fabric properties of the lithofacies, on the pollution fluxes and on the environmental setting (air pollution, meteorological and micro-climatic conditions). The results obtained make it possible to choose suitable lithofacies for the replacement and substitution in the restoration processes in monument of the Guanajuato city.

\section{Resumen}

La Formación Losero juega un papel muy importante en la contribución al patrimonio cultural y arquitectónico de la ciudad de Guanajuato debido a su atractivo color verde y su facilidad para ser trabajada. La Formación Losero fue la piedra natural de construcción más importante durante los siglos XVII y XIX en la ciudad de Guanajuato, representa el principal elemento arquitectónico de la ciudad, la cual se considera Patrimonio de la Humanidad. Después de casi un siglo de exposición, la Formación Losero presenta un deterioro progresivo en muchos edificios de la ciudad (corrosión, descamación, exfoliación, líquenes y formación de grietas). En la mayoría de los casos, el reemplazo total o parcial de estas rocas en los trabajos de restauración no ha tenido éxito, por lo que es necesario tener una comprensión adecuada de las causas que provocan el deterioro de dichas rocas para posteriormente proponer metodologías para su conservación y restauración. En este trabajo se presentan los resultados de un estudio petrofísico de las ocho litofacies más usadas de la Formación Losero en la restauración y construcción de monumentos en la ciudad de Guanajuato (Los Morados, La Veta, Coleto, El Blanquito, El Moyejón, El Verde, La Perla y La Cema), los nombres de las litofacies son informales y fueron denominados así por los canteros locales. Estas litofacies fueron investigadas por las técnicas de microscopía óptica, difracción de rayos X, microscopía electrónica de barrido (SEM) y propiedades físicas (resistencia a la compresión uniaxial, absorción de agua por capilaridad, densidad aparente y real, porosidad total y durabilidad usando la prueba de cristalización de sales), con la finalidad de conocer y comprender las causas que provocan el deterioro de dicho material y proponer un mejor uso de éstas. Los resultados obtenidos demuestran que de las ocho litofacies estudiadas, La veta es la mejor litofacie de la Formación Losero, para utilizarse en columnas, pedestales, escaleras, pisos y zócalos, mientras que La Cema no es recomendable en pilares, balcones y pi-

\section{Descriptores:}

- Formación Losero

- ciudad de Guanajuato

- petrografía

- petrofísica

- construcción y restauración 
sos. La presencia de calcita y caolinita en La Veta y La Cema no la hacen favorable para usarla en exteriores. La Perla, El Moyejón y Coleto, constituyen un material ideal para columnas, pedestales, escaleras y pisos. Los Morados, El Blanquito y El Verde no son recomendables para uso en pilares, balcones y pisos debido a su baja resistencia y dureza. Estos materiales, a pesar de su diferente comportamiento, se ven afectados por factores similares de desgaste que, en orden de importancia y extensión son: intemperismo, ruptura, decoloración, suciedad, líquenes y fisuras. La tasa de deterioro depende de las propiedades de las litofacies, de la contaminación y de la configuración del medio ambiente (contaminación del aire, las condiciones meteorológicas y micro-climáticas). Los resultados obtenidos permiten seleccionar la litofacie adecuada para el reemplazo y sustitución en los procesos de restauración de edificios y monumentos en la ciudad de Guanajuato.

\section{Introduction}

Guanajuato city during the colonial period XVI to XIX centuries was one of the most important cities in New Spain economic, political and social to become the most important mining center of New Spain. Today, Gua- najuato is the main mining area characterized by its production of gold-silver (Figure 1). Nineteenth century architecture in Guanajuato city was mainly neoclassical, the abundance of excellent material, obtained from the hills that the city itself merely adjusting the favored architectural style.

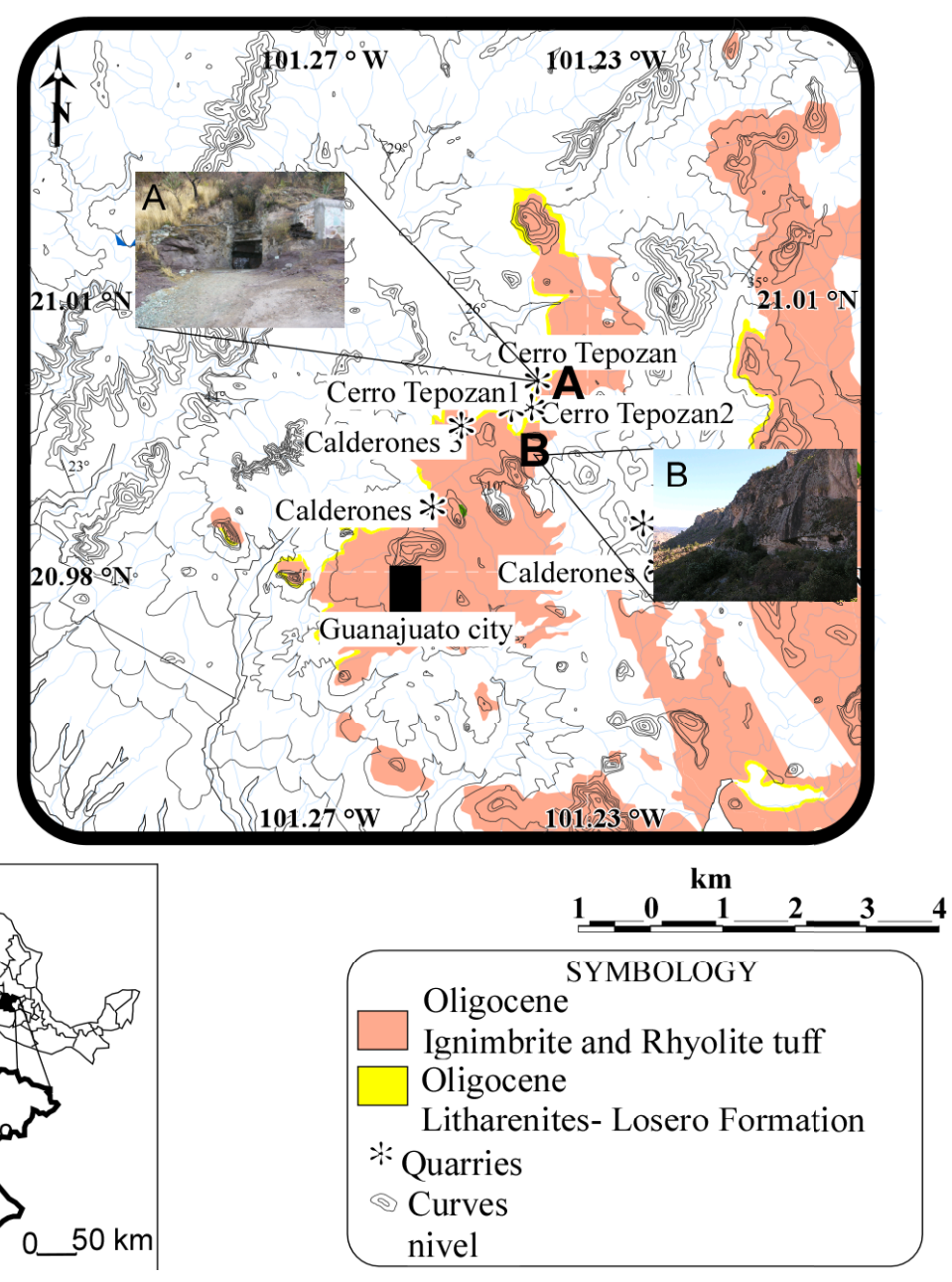

Figure 1. Sketch map of the Guanajuato area: a) Losero Formation quarry, Via Embajadoras; b) Ignimbrite and rhyolite tuff outcrop, Cerro La Bufa locality 
According to Alcocer (1983) the Losero Formation was very widely diffused in the city of Guanajuato, especially until the beginning the XVII and XIX centuries. The quarrying activity of Guanajuato city was firstly established by the villagers to build forts and other buildings during the XVI century (Alcocer, 1983). The maximum stone exploitation was reached during the Porfiriato, when Guanajuato city was preferred by sculptors such as Jesús Contreras, José María Noriega and Antonio Rivas Mercado. Its exploitation and use gradually waned in the second half of XX century, because at that time supplied the local market (Barajas et al., 1981). Today, it has registered six quarries (Figure 1) one of which is active, the Cerro Tepozán, Where stone is extracted for the restoration of monuments and construction of buildings (Figure 2).

Among the numerous construction sites in Guanajuato city in which Losero Formation has been employed, the "Guanajuato University (XIX century)", "Belen church (XVIII century), "the company church,
(XVIII century)", "Alhondiga de Granaditas (XVIII century)", "Principal Theater (XIX century)" and "the Juárez Theater (XIX century)", (Figure 3). These materials, which are still being quarried, are presently valued for color, physical and mechanical properties and the ease to be worked. Nowadays, many problems are reported with the restoration, conservation and construction Losero Formation (corrosion, scaling, spalling and crack formation) (Figure 3).

The causes and mechanisms of the breakdown of Losero Formation are not fully understood. Optical microscopy; X-ray diffraction and Scanning Electron Microscopy (SEM), have been used in the current study to investigate the nature of the decay process observed for Losero Formation. Although it is a widely used material in Guanajuato city architectural heritage, little is know of their petrophysical and mineralogy characteristic. Therefore, the aim for this research is mineralogical and petrophysical characterizations of the Losero Formation to understand and diagnose the present de-
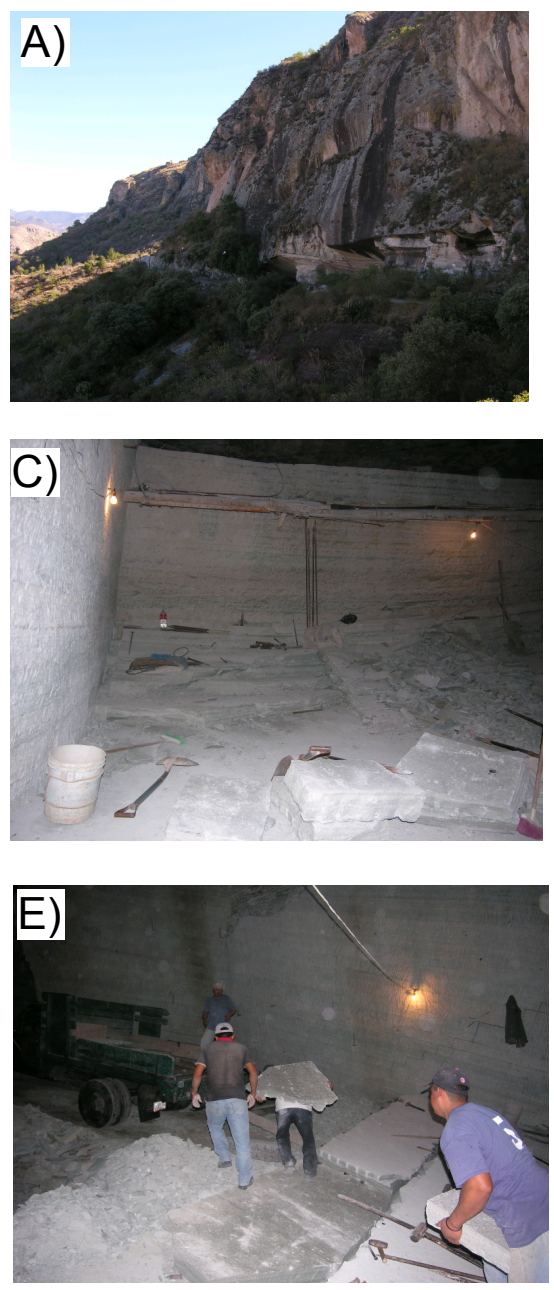
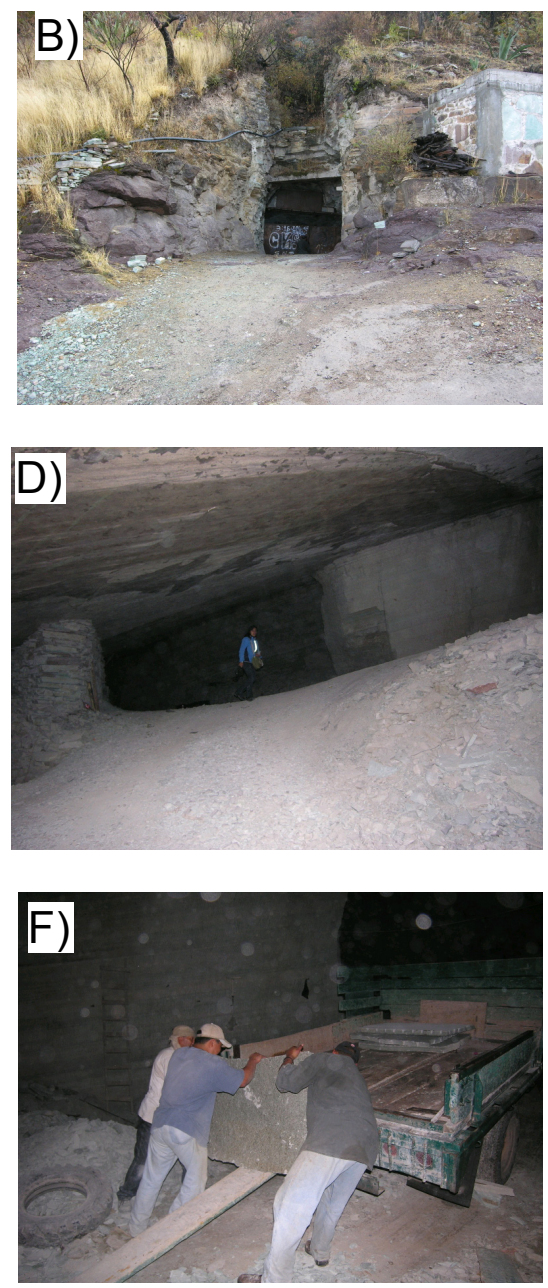

Figure 2. Cerro Tepozán quarry and the extraction of the Losero Formation, a) Cerro La Bufa, b) Cerro Tepozán quarry, c, d, e, f) Inside the Cerro Tepozán quarry 
fects associated with the corrosion, scaling, spalling and crack formation and evaluate its properties for building materials for the conservation and restoration of the monuments.

\section{Losero formation geology}

There are several geology works that mention the Losero Formation, for example, Orozco (1921), described the Losero as greenish sandstone detrital deposits formed by the water-carrying of volcanic tuff. Guiza et al. (1949), mentions that such stone is rhyolitic volcanic ash, of uniform grain similar to the sandstone, are of varying colors from light green to pink is appreciated by the beautiful aspect was preferred as construction material. The thickness of Losero Formation varies bet- ween 12 and 30 meters submitted on the red Conglomerate. Schulze (1953) mentions that Losero Formation is a tuffaceous deposit product from the aqueous-igneous. Randal et al. (1994), mentions that the Losero Formation is a green tuffaceous sandstone of $25 \mathrm{~m}$ of the thickness, is of early Oligocene, because of its stratigraphic position with the Guanajuato conglomerate; for Aranda et al. (2003), the Losero Formation is principally made up of subaerial pyroclastic surge layers and of tuffs of uncertain eruptive style deposited in (and locally reworked by) shallow water and Randall et al. (1994), considered the Losero has a green tuffaceous sandstone, formed in lacustrine conditions. The origin and age of this deposit are still debated. The occurrence of the cross bedding, led some authors to a very complex interpretation of the depositional mechanism as surge
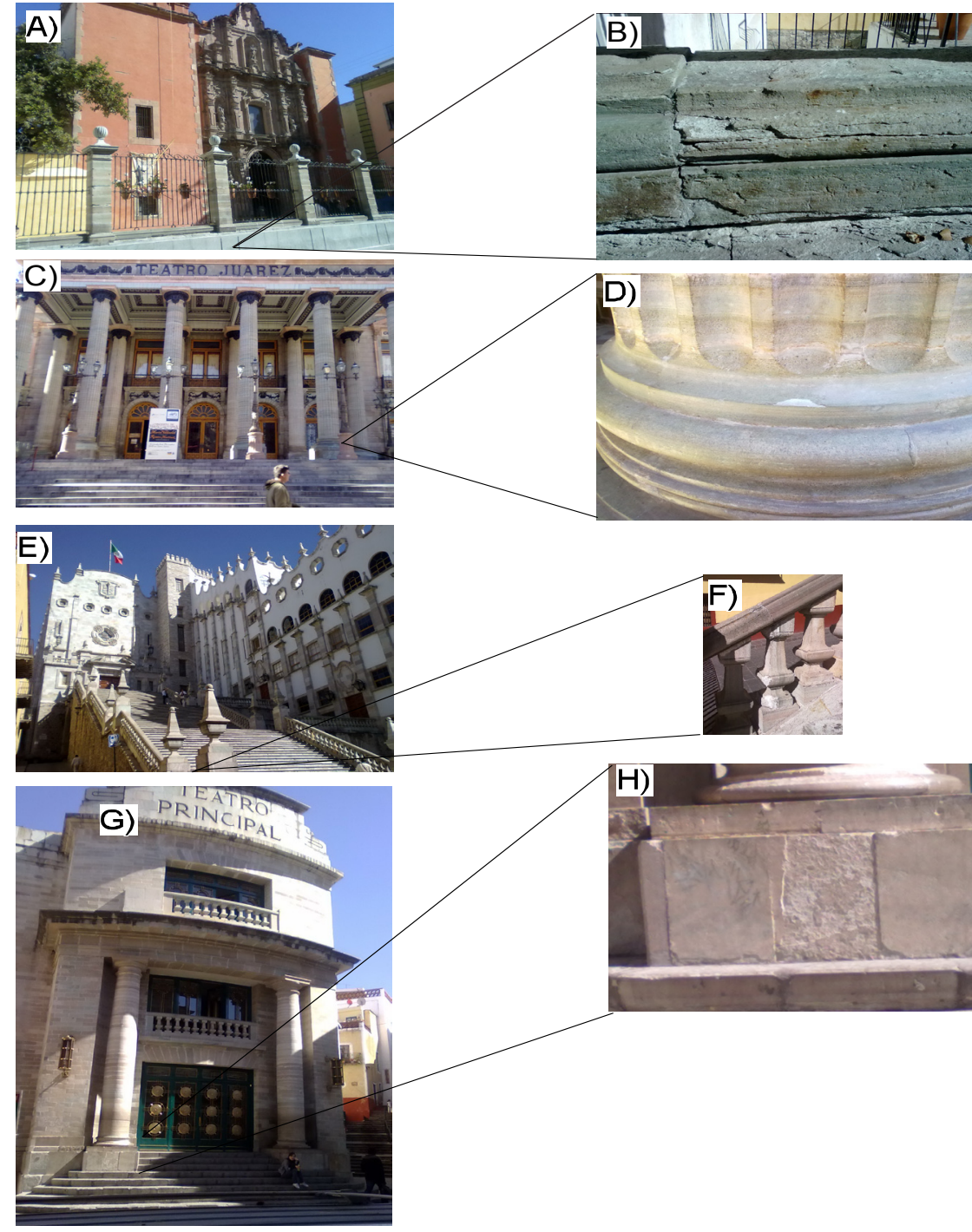

Figure 3. a) Belen church main facade in Guanajuato city. The Losero Formation and ignimbrite and rhyolite tuff, b) A fissure and scaling in the Losero Formation, c) The Juárez Theater, the Losero Formation and ignimbrite and rhyolite tuff, d) Discoloration and scaling, the Losero Formation, e) Guanajuato University, f) Fissure, decoloration and scaling, the Losero Formation, g) The Principal Theater, h) Scaling, the Losero Formation 
deposits (Aranda et al., 2003). The stratigraphy of the Losero Formation is principally made up of subaerial pyroclastic surge layers and of tuffs of uncertain eruptive style deposited in (and locally reworked by) shallow water (Aranda et al., 2003). Two stratigraphic levels can be clearly distinguished (Figure 4).

Using the classification of lithofacies. The lower level (about $5 \mathrm{~m}$ ) is characterized by lithofacies Gm (clastsupported massive gravel), Sh (sand, fine to coarse with horizontal lamination), St (sand fine to very coarse with low angle $\left(<15^{\circ}\right)$ cross bed) and Fm (Mud, silt with desiccation cracks), represented by Los Morados, and La Veta lithofacies (Table 1). The layering usually consists of beds of coarse and fine sand. These units feature cross lamination and horizontal laminated associated with polygonal cracks caused by desiccation. The upper level (about $25 \mathrm{~m}$ ) is characterized by lithofacies Sg (sand fine to very coarse), Sh (sand, fine to coarse with horizontal lamination), represented by Coleto, El Blanquito, El Moyejón, El Verde, La Perla, and La Cema (Table 1). The layering consists of beds of fine sand of green color and horizontal lamination. Ornamental stone quarrying has always been one of Guanajuato most important and dynamic industries. Quarries were scattered across the area delimited by the towns of Calderones, and Guanajuato, although most of the Losero Formation was quarried within the municipal district of Guanajuato (Figure 1).

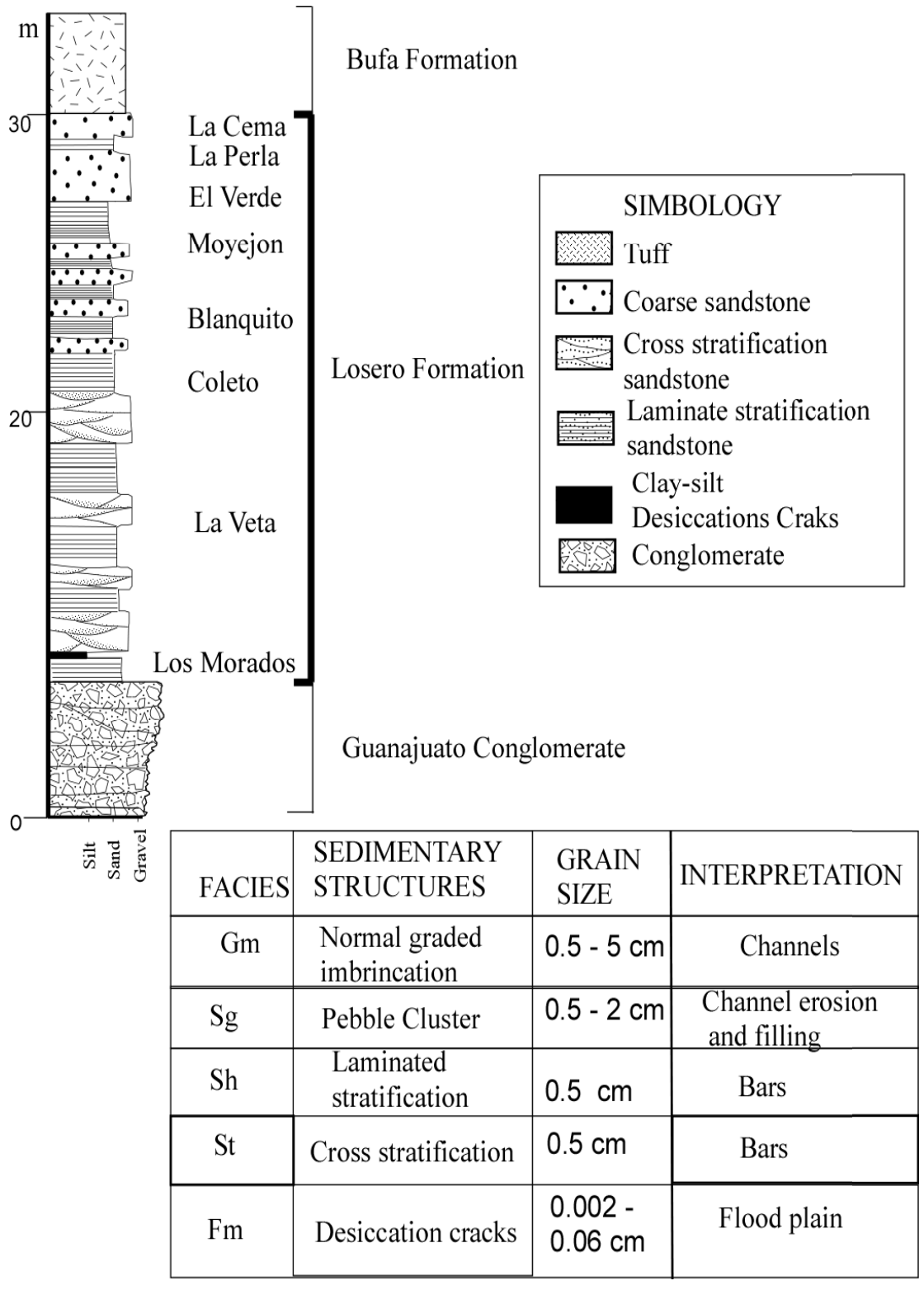

Figure 4. Stratigraphic reconstruction of the Losero Formation in Guanajuato city 
Table 1. Classification of Losero Formation based on lithology, color and color change

\begin{tabular}{|c|c|c|c|c|}
\hline Lithofacie & Sandstone Type (Pettijhon) & Fresh Color & Aged Color & Examples \\
\hline La Cema & $\begin{array}{l}\text { Lithic } \\
\text { arkose }\end{array}$ & Yelow to white & $\begin{array}{l}\text { Brown, White to very } \\
\text { pale yellow }\end{array}$ & $\begin{array}{l}\text { Domestic/landscaping uses } \\
\text { including tiles }\end{array}$ \\
\hline La Perla & $\begin{array}{l}\text { Lithic } \\
\text { arkose }\end{array}$ & Green & Stable & $\begin{array}{l}\text { Domestic/landscaping cladding } \\
\text { uses, window sills, statues }\end{array}$ \\
\hline El Verde & Feldspathic litharenite & Green & Stable & $\begin{array}{l}\text { Belen church, Company church, } \\
\text { stairways Guanajuato university, } \\
\text { window sills. }\end{array}$ \\
\hline El Moyejon & Feldspathic litharenite & Green to cream & White to pale green & Landscaping stone, walls \\
\hline El Blanquito & $\begin{array}{l}\text { Lithic } \\
\text { arkose }\end{array}$ & Green to white & $\begin{array}{l}\text { White to very pale } \\
\text { green }\end{array}$ & Domestic/landscaping uses, \\
\hline Coleto & Feldspathic litharenite & Green & $\begin{array}{l}\text { Stable to very pale } \\
\text { green }\end{array}$ & Exterior paneling \\
\hline La Veta & Litharenite & Green to red & Stable & $\begin{array}{l}\text { Many Guanajuato buildings: } \\
\text { Guanajuato University, Alhondiga } \\
\text { de Granaditas, Juárez theater. }\end{array}$ \\
\hline Los Morados & Litharenite & Red vine & Stable to very pale red & Exterior paneling, walls, floors \\
\hline
\end{tabular}

\section{Methodology}

The research was developed in two distinct phases: the first one was aimed at surveying the lithofacies mined in the quarries applying petrography and mineralogy, the second is the application of mechanical and physical parameters of the materials sampled, such as: physical tests (capillarity water absorption, apparent and real density, total porosity); mechanical test (uniaxial compressive strength), durability (salt crystallization cycles) to evaluate their use in construction and restoration of monuments.

\section{Petrography}

Petrographic investigations of the lithofacies were carried out by optical microscopy Olympus BX41 (OM; plane and crossed polarized light). Petrographic analyses were performed on sixteen thin sections.

\section{Mineralogy}

The crystalline phases investigations of the lithofacies were carried out by X-ray diffraction (XRD) using a Miniflex Rigaku diffractometer having $\mathrm{Cu} K_{\alpha}=1.541874 \AA$ radiation at the "Laboratory of physic" (UNAM), Juriqui1la, Querétaro. In this procedure, we sprayed the size of 0.06 millimeters each of the eight lithofacies of the Lose- ro Formation and took $20 \mathrm{mg}$ of each for its respective analysis.

\section{Scanning electron microscopy (SEM)}

A TM1000, Hitachi scanning electron microscopy (SEM) was used to test the salt crystallization in the sixteen samples. Small samples treated with sodium sulphate were coated with carbon powder to prevent charge-up on the specimen surface and provide a thin conducting layer to the specimen.

\section{Physical test}

\section{Capillarity water absorption}

The amount of water absorbed as a function of time was measured according to the European standard Norma UNE-EN 1925, (1999). The sixteen specimen used for this test had a cubic shape $(5 \mathrm{~cm} \times 5 \mathrm{~cm} \times 5 \mathrm{~cm})$ and a surface $\left(m_{d}\right)$ mass of dry sample in grams; $\left(m_{i}\right)$ masses of sample during test in grams; (A) area of the face under water in $\mathrm{m}^{2}$; (ti) time elapsed since the start of the test until the time when the masses $\left(\mathrm{m}_{\mathrm{i}}\right)$ are measured successive, in second; $\left(\mathrm{C}_{1}\right)$ coefficient of water absorption by capillary perpendicular to the plane of anisotropy of the stone, in $\mathrm{g} / \mathrm{m}^{2} . \mathrm{s}^{0.5} ;\left(\mathrm{C}_{2}\right)$ coefficient of water absorption by capillary parallel to the plane of anisotro- 
py of the stone, in $\mathrm{g} / \mathrm{m}^{2} . \mathrm{s}^{0.5}$. The capillarity absorption coefficient was the following (Equation 1): $\mathrm{C} 1 \mathrm{o} \mathrm{C}_{2}=\mathrm{m}_{\mathrm{i}}$ $-m_{d / 2} A \cdot \sqrt{ } t_{i}$.

\section{Apparent and real density}

Apparent and real density test were carried out on sixteen specimens used the European standard Norma UNE-EN 1936, (2006). The sixteen specimen used for this test had a cubic shape $(5 \mathrm{~cm} \times 5 \mathrm{~cm} \times 5 \mathrm{~cm})$. The apparent density was the following (Equation 2): $\mathrm{P}_{\mathrm{b}}=\mathrm{m}_{\mathrm{d}} / \mathrm{m}_{\mathrm{s}}-\mathrm{m}_{\mathrm{h}}$ $\left(\mathrm{p}_{\mathrm{rh}}\right)$, where $\left(\mathrm{m}_{\mathrm{d}}\right)$ is mass of dry specimen in grams; $\left(\mathrm{m}_{\mathrm{s}}\right)$ mass of satured specimen in grams; $\left(m_{h}\right)$ mass of the specimen immersed in water in grams; $\left(\mathrm{p}_{\mathrm{rh}}\right)$ water density in kilograms per cubic meter. The real density was the following (Equation 3): $\mathrm{P}_{\mathrm{r}}=\mathrm{m}_{\mathrm{e}} / \mathrm{V}_{\mathrm{s}}\left(\mathrm{p}_{\mathrm{rh}}\right)$, where $\left(\mathrm{m}_{\mathrm{e}}\right)$ is mass of crushed and dry specimen in grams; $\left(\mathrm{V}_{\mathrm{s}}\right)$ is the volume of liquid displaced by the mass $\mathrm{m}_{\mathrm{e}} ;\left(\mathrm{p}_{\mathrm{rh}}\right)$ water density in kilograms per cubic meter.

\section{Total porosity}

The total porosity test were carried out on sixteen specimens used the European standard Norma UNE-EN 1936, (2006). Total porosity was calculated using the relationship between the volume of the pores (open and closed) and the apparent volume of the specimen, with the equation $4: \mathrm{p}=\left(1-\mathrm{p}_{\mathrm{b}} / \mathrm{p}_{\mathrm{r}}\right) \times 100$, where $\left(\mathrm{p}_{\mathrm{b}}\right)$ is apparent density and $\left(\mathrm{p}_{\mathrm{r}}\right)$ real density.

\section{Mechanical test}

\section{Uniaxial compressive strength}

Uniaxial compressive strength test were also performed in order to determine the maximum value of stress reached before failure. Uniaxial compressive strength (UCS) tests were carried out on sixteen specimens using the European Standard Norm UNE-EN1926, (2006). The cubic samples $(5 \mathrm{~cm} \times 5 \mathrm{~cm} \times 5 \mathrm{~cm})$ were cut parallel and perpendicular to the sediment bedding in order to obtain information about mechanical isotropy. The testing device (Universal Press Forney apparatus) allowed a maximum axial load of $1471 \mathrm{kN}$. The axial load was increased continuously at a rate within the limits of rupture $(1336 \mathrm{kN})$. Load and strain were continuously registered; sampling time interval was between 2 and 3 min.

\section{Durability (Salt crystallization test)}

Resistance to salt crystallization was tested using the European Standard Norm UNE-EN 12370 (2006). Salt- loading tests in the laboratory were carried out to verify the weathering susceptibility of the sixteen samples. For this purpose crystallization tests by means of sodium sulphate were carried out on a number of stone cubes $(5 \mathrm{~cm} \times 5 \mathrm{~cm} \times 5 \mathrm{~cm})$. Standard salt crystallization tests typically use sodium sulphate because it is the most harmful salt, generating visible signs of alteration more rapidly than other salts. The test usually consists in immersing the rock wholly or partially in a solution containing a single salt.

\section{Experimental data and results}

\section{Petrography}

The Losero Formation show a great diversity in grain sizes, from coarse to fine sand. The grains generally are subrounded to angular and show a poor selection. Regarding to composition these sandstones are immature, with high contents of rock fragments in size from some micrometers up to several millimeters. Petrographic analyses were performed on sixteen thin sections; the samples came from the quarry Cerro Tepozán. Optical microscopy analyses show that all the lithofacies present quartz, feldspars, biotite, volcanic lithics, metamorphic lithics and iron oxides in small quantities. Los Morados, Coleto, and La Perla to be characterized by a high percentage of metamorphic lithics (20-25\%) and a low percentage of volcanic lithics (4-15\%), and a high percentage of quartz-feldspars (15-38\%). La Veta, El Blanquito, El Moyejón, El Verde, and La Cema exhibited a high percentage of quartz-feldspars (17-40\%), a low percentage of metamorphic lithics (15-19\%) and a low percentage of volcanic lithics (4-20\%) (Figure 5).

The analyses carried out according to the method of Dickinson (1985) show that the stones are composed dominantly by monocrystalline quartz (35\%), K-feldspar $(20 \%)$, rock fragments of metamorphic (quartzites (19\%), phyllites (10\%)) and volcanic (andesitic (16\%)), as accessories biotites and opaque minerals (hematite) (Figure 5). The mineral alterations are chlorite and sericite. The matrix is composed of fine-grained silica. From petrography, the Losero Formation was identified as a lithic arkose to litharenite, according to the classification of Folk et al. (1970).

\section{Mineralogy}

Crystalline phases were identified using a Miniflex Rigaku diffractometer having $\mathrm{Cu} K_{\alpha}=1.541874 \AA$ radiation. Diffraction intensity as a function of the angle $2 \theta$ was measured between 5 and 80 degrees with a step of 
a)

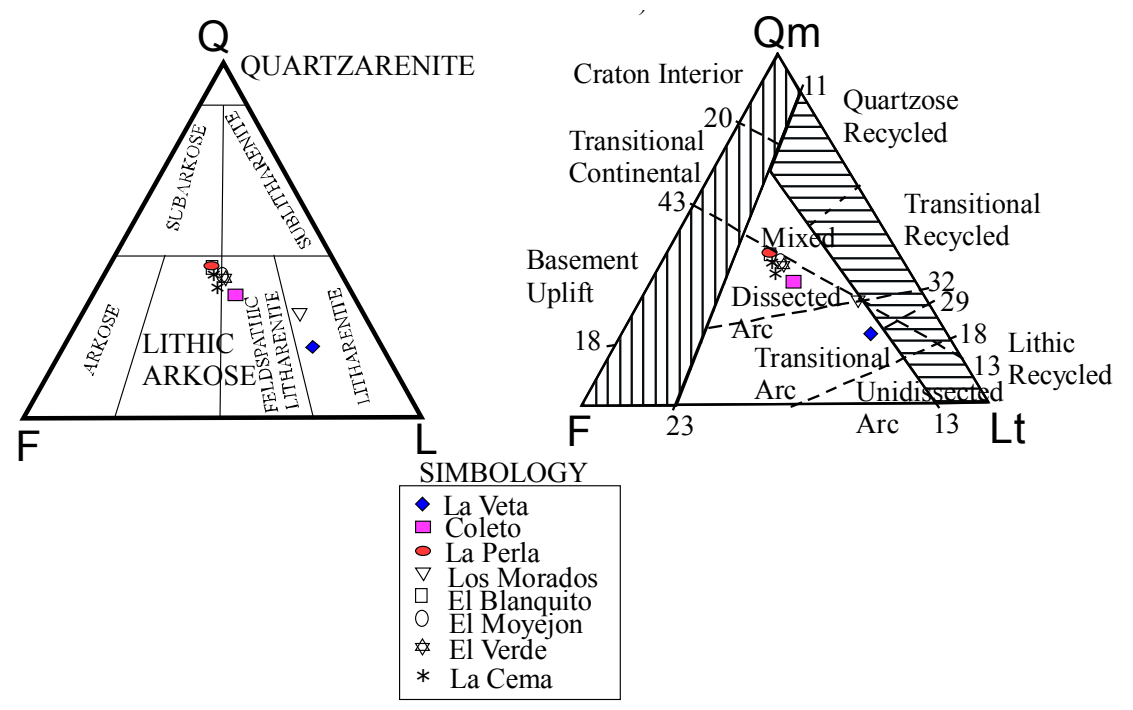

c)

\begin{tabular}{lccccccccccc}
\multicolumn{10}{c}{} & \multicolumn{1}{c}{ QmFL \% } & QtFLt \% \\
\hline $\begin{array}{l}\text { Mineralogical } \\
\text { Composition (\%) }\end{array}$ & Qm & F & Lt & Qt & F & Lt & Qp & Lv & Lm & Biotite & $\begin{array}{c}\text { Iron } \\
\text { oxides }\end{array}$ \\
\hline Los Morados & 36 & 15 & 20 & 52 & 15 & 20 & 16 & 15 & 25 & 5 & 4 \\
La Veta & 33 & 17 & 19 & 45 & 17 & 19 & 12 & 20 & 19 & 7 & 4 \\
Coleto & 31 & 26 & 14 & 45 & 26 & 14 & 14 & 5 & 24 & 10 & 4 \\
El Blanquito & 38 & 28 & 10 & 46 & 28 & 10 & 8 & 10 & 10 & 5 & 4 \\
El Moyejon & 36 & 27 & 14 & 46 & 27 & 14 & 10 & 10 & 18 & 5 & 4 \\
El vVerde & 33 & 25 & 16 & 43 & 25 & 16 & 10 & 4 & 18 & 16 & 4 \\
La Perla & 38 & 29 & 12 & 50 & 29 & 12 & 12 & 4 & 20 & 5 & 4 \\
La Cama & 40 & 30 & 15 & 50 & 30 & 15 & 10 & 5 & 16 & 5 & 4 \\
\hline
\end{tabular}

Figure 5. a) Classification of the Losero Formation in accordance with Folk et al. (1970), b) Classification of the Losero Formation in accordance with Dickinson (1985), c) Mineralogical composition (\%). We counted 500 points by thin section
0.02 and a scan speed of 2 degrees per minute. The results show that all sandstones present crystalline phases of quartz and albite and lesser proportion of muscovite. The difference between these sandstones is the present of carbonate (calcite) and clay (Kaolinite). La Veta and La Cema showed calcite and kaolinite while La Perla, Los Morados, Coleto, El Blanquito, El Moyejón, and El Verde have not presented these crystalline phases (Figure 6).

These lithofacies showed similar real density values in terms of bulk density values, the La Cema, La Perla, Los Morados, and El Verde range from (2.67 to $\left.2.43 \mathrm{gr} / \mathrm{cm}^{3}\right)$.These lithofacies no water swelling and low-medium porosity (2.94-7.55\%) to medium-high porosity (9.41-18.54\%). The capillarity water absorption ranged from $2.84 \%$ in La Veta to $4.63 \%$ in La
Cema. The La Veta, Los Morados, Coleto, and El Verde lithofacies exhibited similar behavior, which differed from the behavior observed in El Blanquito, La Perla, El Moyejón, and La Cema. The coefficient of water absorption by capillary perpendicular to the plane of anisotropy was similar for Coleto, El Moyejón, and La Perla, with values of $0.06 \mathrm{~g} / \mathrm{cm}^{2} . \mathrm{s}^{0.5}$ in 120 minutes respectively, while, La Cema shows the lowest value $\left(0.04 \mathrm{~g} / \mathrm{cm}^{2} . \mathrm{s}^{0.5}\right)$, and Los Morados, La Veta, El Verde, and El Blanquito showed value of $0.05 \mathrm{~g} / \mathrm{cm}^{2} . \mathrm{s}^{0.5}$ (Figure 7). Slight differences between specimens of the same lithofacies should be related to the heterogeneity of the materials. It is noteworthy that no significant differences in the coefficient of water absorption by capillary parallel to the plane of anisotropy. 


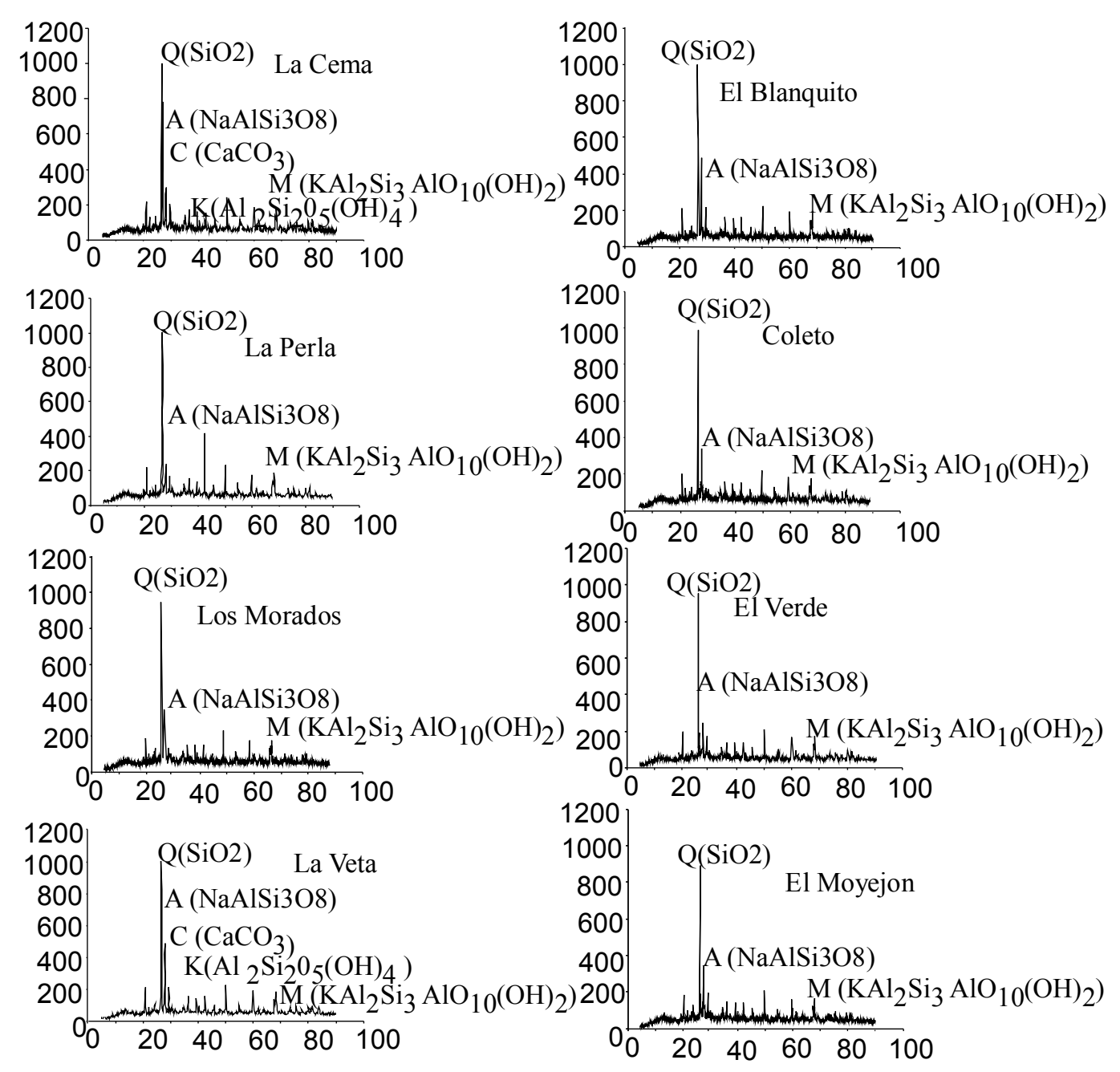

Figure 6. XRD patterns of the Losero Formation. K, kaolinite; Q, quartz; C, calcite, A, albite; M, muscovite

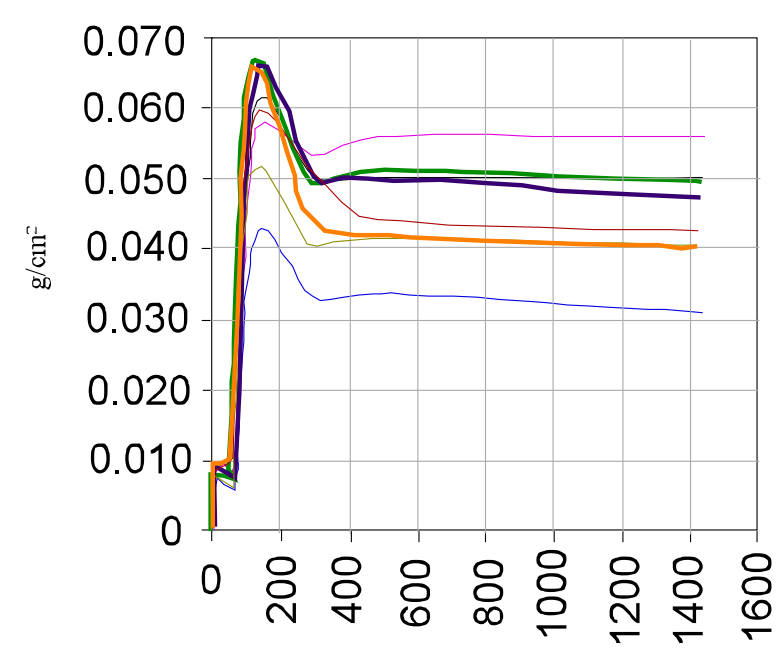

Time $(\mathrm{s} 1 / 2)$
Losero Formation

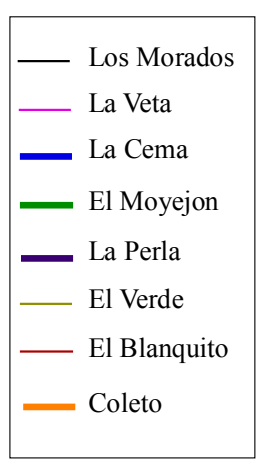

Figure 7. Capillarity water absorption coefficient of the Losero Formation 
Table 2. Apparent density, Real density, Water absorption, Water absorption coefficient and Total porosity of Losero Formation

\begin{tabular}{|c|c|c|c|c|c|c|c|c|}
\hline & La Cema & La Perla & El Verde & El Moyejón & El Blanquito & Coleto & La Veta & Los Morados \\
\hline $\begin{array}{l}\text { Apparent density } \\
\left(\mathrm{gr} / \mathrm{cm}^{3}\right)\end{array}$ & 2.621 & 2.674 & 2.436 & 2.173 & 2.306 & 2.214 & 2.491 & 2.533 \\
\hline $\begin{array}{l}\text { Real density } \\
\left(\mathrm{gr} / \mathrm{cm}^{3}\right)\end{array}$ & 2.79 & 2.755 & 2.788 & 2.748 & 2.755 & 2.718 & 2.75 & 2.74 \\
\hline Absorption (\%) & 4.63 & 4.40 & 3.37 & 4.58 & 4.25 & 3.95 & 2.84 & 3.68 \\
\hline $\begin{array}{l}\text { Coefficient of water absorption } \\
\text { by capillary perpendicular to the } \\
\text { plane of anisotropy ( } 120 \text { minutes) } \\
\left(\mathrm{g} / \mathrm{cm}^{2} \cdot \mathrm{s}^{0.5}\right)\end{array}$ & 0.04 & 0.06 & 0.05 & 0.06 & 0.05 & 0.06 & 0.05 & 0.05 \\
\hline Total Porosity & 6.09 & 2.94 & 12.62 & 20.92 & 16.29 & 18.54 & 9.41 & 7.55 \\
\hline
\end{tabular}

\section{Physic parameters}

The results of the physical parameters are summarized in Table 2.

\section{Mechanical parameters}

The results of the mechanical tests are given in Figure 8. These tests were conducted on specimens using different load orientations, subsequently carried out a statistical study of analysis of variance to assess the behavior of the material. The results showed that the sixteen lithofacies exhibited different behavior depending on the property tested. Los Morados, El Blanquito, and La Cema had a lower strength values when the load was applied parallel to the bedding planes, while El Verde, La Perla, El Moyejón, Coleto, and La Veta showed a high strength values. Is important to mention that all the samples showed a better strength values when the load was applied perpendicular to their planes.

\section{Durability (Salt crystallization test)}

Durability was estimated in these materials by sodium sulphate salt crystallization. The salt crystallization test was used to evaluate damage caused by soluble salts that penetrate stone and subsequently crystallize in its voids (pores or cracks). After 15 salt crystallization cycles the specimen surface was inspected for change in appearance. A slight weight loss and gain was recorded for all the sandstones when submerged in the saline solution. The material released was primarily rock frag- ments. Weight loss and gain is given in table 3 as percentage.

No weight loss was detected in La Perla, El Moyejón, El Blanquito, Coleto, La Veta, and Los Morados, however there was a weight loss in La Cema, and El Verde. These differences in behaviors were attributed to the fact that rock fragments clusters in La Cema, and El Verde also to present anisotropy plane. Lastly, polished sections of the sixteen lithofacies were observed under a binocular microscope. When viewed with sidelight, the secondary pore network vugs afforded further insight into the clearly differentiated behavior of the sixteen lithofacies. SEM observations revealed the existence of salts filling cavities in La Cema, and El Verde (Figure 9).

Table 3. Variation in mass $(\Delta \mathrm{M}(\%))$ of Losero Formation

\begin{tabular}{lc}
\hline \multicolumn{1}{c}{ Losero Lithofacies } & $\Delta \mathrm{M}(\%)$ \\
\hline La Cema & -0.07 \\
La Perla & 0.29 \\
El Verde & -0.24 \\
El Moyejón & 0.61 \\
El Blanquito & 0.75 \\
Coleto & 0.52 \\
La Veta & 0.23 \\
Los Morados & 0.39 \\
\hline
\end{tabular}



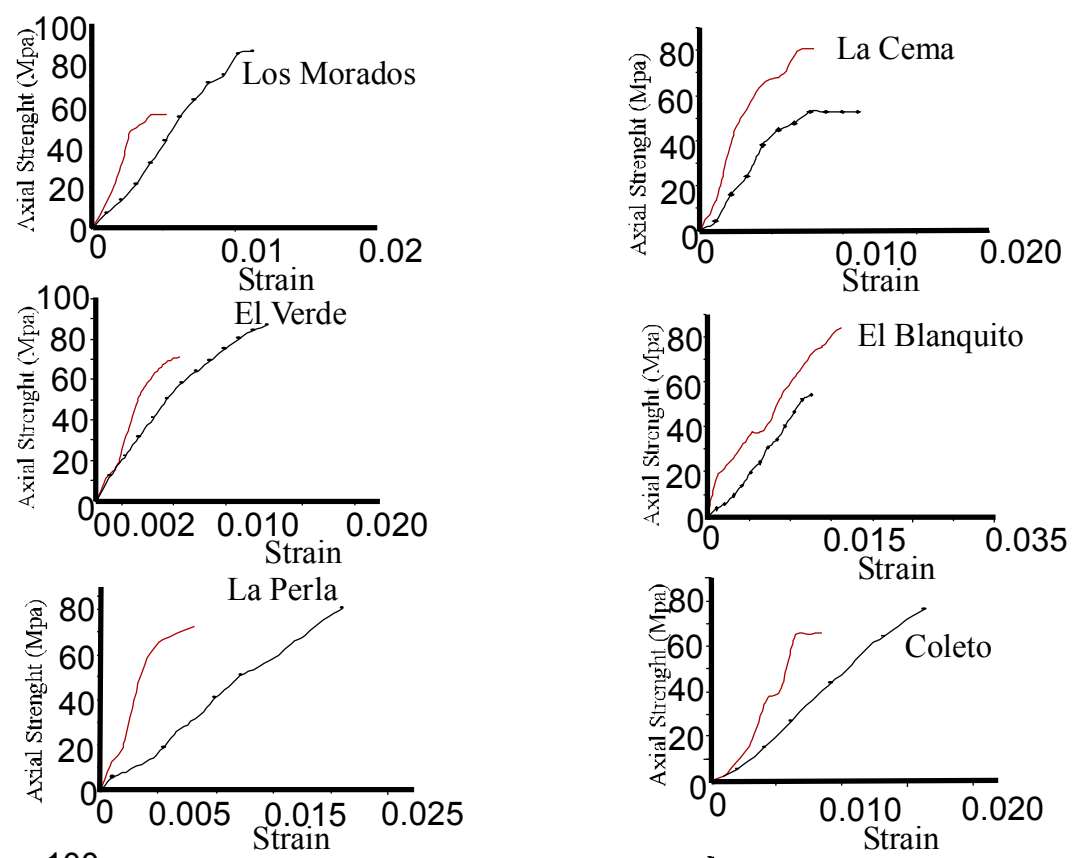

\begin{tabular}{|c|c|c|}
\hline 0 & $0.005 \begin{array}{c}0.015 \\
\text { Strain }\end{array}$ & 0.025 \\
\hline $\begin{array}{l}\text { Losero } \\
\text { Stone }\end{array}$ & $\begin{array}{l}\text { Compressive } \\
\text { Strength Planes } \\
\text { parallel anisotropy } \\
(\mathrm{Mpa}) \\
\end{array}$ & $\begin{array}{l}\text { Compressive Strength } \\
\text { Planes perpendicular } \\
\text { anisotropy(Mpa) }\end{array}$ \\
\hline Los Morados & 55.83 & 86.81 \\
\hline La Veta & 62.36 & 98.44 \\
\hline Coleto & 65.76 & 76.37 \\
\hline El Blanquito & 54.46 & 84.10 \\
\hline El Moyejon & 77.41 & 86.81 \\
\hline El Verde & 71.63 & 86.75 \\
\hline La Perla & 72.82 & 80.68 \\
\hline La Cema & 52.83 & 80.57 \\
\hline
\end{tabular}

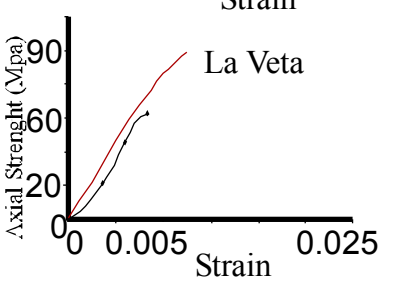

- Parallel to the planes of anisotropy

- Perpendicular to the planes of anisotropy

Figure 8. Uniaxial compressive strength of the Losero Formation

\section{Discussion and conclusions}

After several centuries of exploitation and usage in the architecture of the ancient centre of Guanajuato, Losero Formation has been thoroughly studied here from different points of view, namely mineralogy, petrography, and mechanical. The Losero Formation in its different varieties has been widely used as building stones in the historical and modern architecture of Guanajuato city. Among them, Losero Formation certainly represents an important case history, as this stone was used in both monumental and ordinary buildings; in many cases, the most used lithofacies are La Veta, La Cema, and La Perla. The research evidenced that the use of different lithofacies was conditioned by their availability and their different petrophysical features. Petrographic and mineralogical analyses carried out on the Losero Formation allow us to classify the lithofacies as lithic arkose to litharenite. The petrographical studies reveal significant differences between the lithofacies. The La Cema, and La Perla exhibit a similar composition while not so with the La Veta. The high percentage of lithic fragments content and a low percentage of quartz-feldspars in La Veta is the result of transitional arc processes provenance (Figure 5), while La Cema and La Perla exhibited a high percentage of quartz-feldspars and a low percentage of volcanic lithics showing a dissected arc processes provenance 

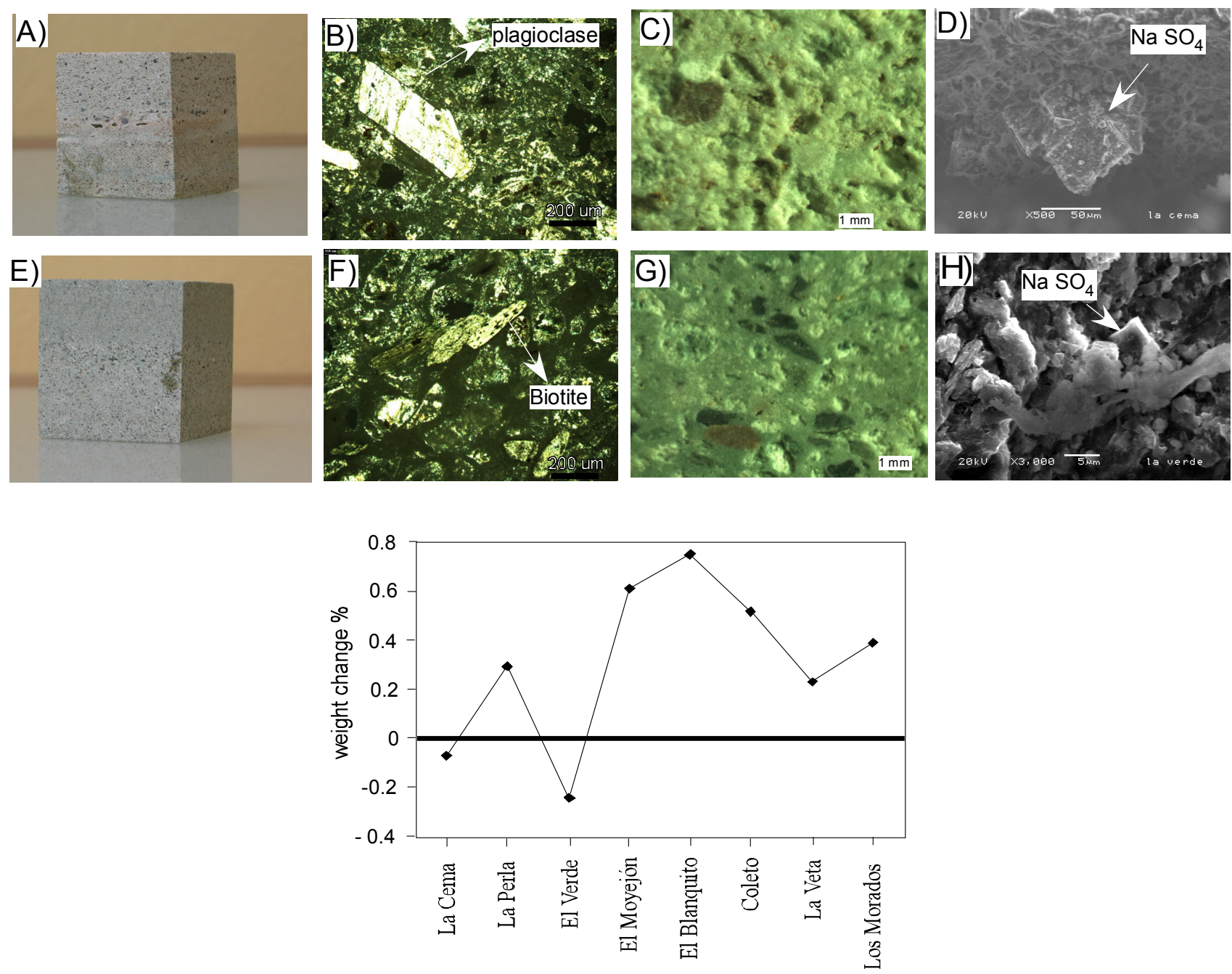

Figure 9. Samples, petrographic features in thin section, binocular microscope and SEM images, a) The La Cema sandstone, b) The La Cema sandstone, crossed nicols, c) The La Cema sandstone, binocular microscope image, d) A salt crystal in the La Cema sandstone, scanning electron microscopy image, e) The El Verde sandstone, f) The El Verde sandstone, crossed nicols, g) The El Verde sandstone, binocular microscope image, h) A salt crystal in the El Verde sandstone, scanning electron microscopy image

(Figure 5). From a mineralogical point of view, the calcite and kaolinite enable us to differentiate the Losero Formation. The presence of calcite and kaolinite in La Veta, and La Cema, make them unfavorable for outdoor use. The favorable petrophysical and mechanical properties of Losero Formation explain why it is an excellent natural building material. The high compressive strength, durability and coefficient of water absorption in La Perla, El Moyejón, Coleto, and La Veta made it an ideal material for columns, pedestals, staircases, flooring, and baseboards, as well as for pavement cobbles or curbing. Los Morados, El Blanquito, El Verde, and La Cema exhibited low strength, durability and coefficient of water absorption values so they cannot be used as pillars, balconies, and floors. El Moyejón, El
Verde, and La Perla are suitable for use in monuments and pillars according to the very favorable results of the resistance test. Salt crystallization, which depends on fluid transfer, evaporation and ion concentration in the solutions, may be affected by clay mineral reactivity, resulting in significant stone damage as is the case of the La Veta, and La Cema. The eight lithofacies of the Losero Formation are recommended for both the restoration of historic buildings and new construction.

\section{Acknowledgements}

The research was carried out with the financial support of DINPO- University of Guanajuato, project 000044/09. The authors wish to thank Engineer Miguel Angel He- 
rrera Bermudez for the mechanical analysis performed in the Laboratory of soil mechanics, materials and asphalt, of the Civil Engineering Department.

\section{References}

Alcocer-Martínez A . El agua en la ciudad de Guanajuato: problema de siglos, Proyecto Puentecillas, Universidad de Guanajuato, Museo de la Alhóndiga de Granaditas, Observatorio Astronómico y Meteorológico de la Universidad de Guanajuato, 1983, p. 30.

Aranda-Gómez J.J., Godchaux M.M., Aguirre-Díaz G.J., Bonnichsen B., Martínez-Reyes J. Continental Edge Tectonics of Isla Tiburón, Sonora, México, on: Geologic transects Across Cordilleran Mexico, Guidebook for the Field Trips of the 99th Geological Society of America Cordilleran Section Annual Meeting, Puerto Vallarta, Jalisco, México, April 5-8, 2003, Universidad Nacional Autónoma de México. Instituto de Geología, publicación especial 1, Field trip 6, 2003: 123-168.

Barajas-León R., Hernández-Montiel M.F., Acasio-Alvarado J. Consideraciones para la reglamentación de la construcción en la ciudad de Guanajuato: 450 años de historia constructiva, tesis (profesional), México, Facultad de Arquitectura, Universidad de Guanajuato, 1981, 21 p.

Dickinson W.R. Interpreting Provenance Relation from Detrital Modes of Sandstones, on: Zuffa G.G. (ed.). Provenance of Arenites: NATO ASI Series, C 148, D. Reidel Publishing Company, Dordrecht, 1985, pp. 333-363.

Folk R.L., Andrews P.B., Lewis D.W. Detrital Sedimentary Rock Classification and Nomenclature for Use in New Zeland. New Zeland Journal of Geology and Geophysics, volume 13, 1970: 937-968.

Guiza R., Rendón F., Baltierra J.J. Estudio geológico del Distrito Minero de Guanajuato, Gto. (Zona de la veta Madre), México, Instituto Nacional para la Investigación de Recursos Minerales, 22, 1949.
Norma UNE-EN1926: Métodos de ensayo para piedra natural. Determinación de la resistencia a la compresión, 2006.

Norma UNE-EN 1936: Métodos de ensayo para piedra natural. Determinación de la densidad real y aparente y de la porosidad abierta y total, 2006.

Norma UNE-EN 12370: Métodos de ensayo para piedra natural. Determinación de la resistencia a la cristalización de sales, 2006.

Norma UNE-EN 1925: Métodos de ensayo para piedra natural. Determinación del coeficiente de absorción de agua por capilaridad, 1999.

Orozco R. La industria minera de México, Distrito de Guanajuato, Secretaría de Educación Pública, 1921, 163 p.

Randall-Roberts J.A., Saldaña E., Clark K.F. Exploration in a Volcano-Plutonic Center at Guanajuato, México. Economic Geology, volume 89, 1994: 1722-1751.

Schulze-Ziehl. Observaciones geológicas y patogénicas en el mineral de Guanajuato, con referencia especial al "Losero". Servicio Geológico Mexicano, archivo técnico, Clave 1153SCRG0001, 1953.

\section{Citation for this article:}

\section{Chicago citación style}

Puy-Alquiza, María Jesús, Raúl Miranda-Avilés, Carmen SalazarHernández, Marina Vega-González, Jorge Cervantes. Characterization Petrophysical of the Losero Formation in the Historical Architecture of the Guanajuato City, Mexico. Ingeniería Investigación y Tecnología, XIV, 02 (2013): 191-205.

\section{ISO 690 citation style}

Puy-Alquiza M.J., Miranda-Avilés R., Salazar-Hernández C., VegaGonzález M., Cervantes J. Characterization Petrophysical of the Losero Formation in the Historical Architecture of the Guanajuato City, Mexico. Ingeniería Investigación y Tecnología, volume XIV (issue 2), April-June 2013: 191-205. 


\section{About the authors}

María Jesús Puy-Alquiza. Is a geologist by profession, received her Ph.D. in stratigraphy from the Centro de Investigaciones de Ciencias Marinas in Baja California Sur, Mexico. She is currently a research professor at the University of Guanajuato. Her lines of interest are stratigraphy and sedimentology, geological heritage valuation. Her recent publication is "Stratigraphic review of Punta Coyote (Baja California Sur, Mexico) and implications for the volcanism of the Sierra Madre Occidental and the Comondu arc" (Estudios Geologicos).

Raúl Miranda-Avilés. Is a geologist by profession, received his Ph.D. in geology from the University of Bordeaux, France. He is currently a research professor at the University of Guanajuato. His lines of interest are Image processing for the exploration of mineral deposits, structural geology, and geological heritage valuation. His recent publication is "Anthropogenic metal content and natural background of overbank sediments from the mining district of Guanajuato, Mexico" (Soil and Sediment Contamination An International Journal).

Carmen Salazar-Hernández. Is a chemist by profession, received her Ph.D Ph.D. in chemistry from University of Guanajuato, Mexico. Works today as professorresearcher at the Instituto Politecnico Nacional. Her lines of interest are Synthesis and application of silicon compounds in architectural conservation problems, and Organometallic chemistry of silicon and other elements of group 14. Her recent publication is "Colloidal silica-PDMS-OH hybrid formulation used for stone consolidation" (Applied organometallic-chemistry).

Marina Vega-González. Works today as Academy technician at Universidad Nacional Autonoma de Mexico, Juriquilla, Queretaro. Head of the Laboratory of Fluid Technique Cortical Geoscience Center and head of Scanning Electron Microscope. Her lines of interest are Crystallography of inorganic materials, nanomaterials and geological materials, and refinement of crystal structures by the Rietveld method.

Jorge Armando Cervantes-Jauregui. Is a chemistry by profession, received her Ph.D in chemistry in University Metropolitana, México. He is currently a research professor in the University of Guanajuato. Her lines of interest are Synthesis and application of silicon compounds in architectural conservation problems, and Organometallic chemistry of silicon and other elements of group 14. Her recent publication is "Colloidal silica-PDMS-OH hybrid formulation used for stone consolidation" (Applied organometallic-chemistry). 